\title{
Methodological Considerations in Data Collection for Language Learning in a Study Abroad Context
}

\author{
Th o m H u b n e r
}

San Jose State University

\section{Introduction}

To the extent that study abroad (SA) programs are intended to enhance the language skills of their participants, the design, implementation, and evaluation of them must address the issue of how best one acquires a second language, which in turn entails other questions: What does it mean to acquire a second language? How is the acquisition of another language measured and/or evaluated? How does the SA experience affect it? At least two factors contribute to the fact that these rich data sources are not exploited for answers to these questions more than they are. First, the range of experiences which fall under the rubric of "study abroad" is so varied and complex that generalizations about optimal learning contexts need to be made with great caution. Second, often those best positioned to study this aspect of the SA experience, namely program administrators and teachers, are trained in disciplines which do not prepare them for this task. The purpose of this paper is to outline a series of factors that together provide a framework for looking at SA and to outline some research approaches, methods and techniques appropriate for examining the language acquisition aspects of this experience.

A primary benefit of examining analytically the SA experience from a linguistic perspective is internal. They are a common component of many foreign language programs across the country and need to be eval- 
uated as such. Lambert, for example, reports that "a substantial number of higher-education institutions maintain study abroad programs for their students, and one in three four-year institutions operate language programs either on their own or as part of a consortium" (1994:135). Yet, systematic evaluation of these programs in terms of language development is the exception rather than the norm.

A second reason for looking at language acquisition within the SA context is that potential benefits and advancements to the language teaching profession accrue. With the heightened awareness of the need for foreign language proficiency, traditional models of foreign language instruction have been subject to re-examination. This, together with the burgeoning research in second language acquisition (SLA) over the past two decades, has led to a renewed attention to alternative models of delivery, models which incorporate features believed to contribute to foreign language proficiency. These include the addition of task-based, communication-oriented interactional components to the curriculum, summer intensive courses and year-round learning, and academic discipline-based courses offered in the target language. By their very nature SA programs subsume many features of these alternative delivery models. Students in a junior year abroad program, for example, are often expected to take courses in the major or minor in the target language. A program designed for a graduate level student pursuing an advanced degree in a specialized area might include an intensive foreign language component. And SA programs which are preliminary to an extended work experience abroad, such as in the Peace Corps, often expect continued development after the initial formal SA is completed.

The central trait of all SA programs aimed at increasing foreign language proficiency is the opportunity they provide for informal out-of-class exposure to the target language. The benefits of this type of exposure to the target language for the development of second language proficiency is more than a common folk belief. It is also a question of central concern for SLA theory. It has been shown that in conversations with second language learners, native speakers adjust their speech in order for both parties to better understand what is meant (e.g., Ferguson 1971, 1975; Freed 1978; Long 1981). This "negotiation of meaning" not only facilitates understanding, it is now commonly believed among many researchers that "conversational interaction forms the basis for the development of syntax" 
(Gass and Selinker 1994:216). While informal exposure without instruction may not be sufficient for successful second language learning, there is support for the position that in combination with formal instruction, it helps learners to develop greater second language proficiency (cf. Ellis 1994:616).

Since Carroll's (1967) report that time spent abroad was one of the major predictors of foreign language proficiency among 2,782 college seniors, it has been assumed that the out-of-class contact afforded by the SA experience was to a large extent responsible for this finding. Yet despite the importance of data from SA programs for important issues in SLA and foreign language education, research into the linguistic effects of SA is only beginning to emerge (see, for example, Brecht and Walton 1994; Freed 1995a).

It is precisely because SA programs deal directly with these SLA issues, and because of the dearth of empirical data available, that SA program administrators, teachers and researchers must look not only at their own programs, but also at the range of programs confronting these same issues. More broadly, this includes language learning situations which involve some form of informal learning within a target language context, such as immersion bilingual programs and the experiences of immigrants and foreign students in this country.

The next sections will review variables within the context of an SA program, how they are likely to effect language learning outcomes, and why, consequently, they need to be taken into account when looking at the effectiveness of SA programs. These include institutional program features, or "the architecture of institutional types" (Lambert 1994), program goals, types of languages targeted, target populations, and program and course design. The paper then turns to a broad outline of major research approaches and techniques which can be and have been employed in looking at the linguistic effects of SA. The conclusion discusses possible ways in which the rich vein of SA can be better tapped by all of those who have an interest in the answers to questions which that experience raises.

\section{The Architecture of Institutional Types}

When one considers SA, perhaps one most often thinks of university-based programs. Of course, they comprise only a part, albeit a major 
part, of the "national architecture" (Lambert 1994) of overseas study in this country. Within the formal K-16 system, foreign exchange programs such as those sponsored by the American Field Service (AFS) provide SA experiences for secondary school students. The federal government is involved in SA with programs such as the Peace Corps (Gunterman 1995, $1992 a, 1992 b)$ and the Foreign Service Institute. A system of private language schools also offers SA experiences for American students of all ages. At the informal level, there are the experiences of individuals who go abroad for the purpose of increasing foreign language proficiency, but without enrolling in any form of formal language instruction.

Conversely, not all SA programs include a goal of enhanced foreign language proficiency. Exchange programs to other English-speaking countries most immediately come to mind, but other programs, offered in non-English-speaking countries, may import in toto the curriculum from the home institution, including the native language as a medium of instruction. In programs with a foreign language (FL) instructional component, that component may be intensive or not. Among programs with non-intensive FL components, some offer companion courses in the major or minor field or area of concentration in English to the American students isolated from their counterparts in the host country institutions. Others expect students to fill out their schedule with courses from the regular offerings of the host country institution with the target language as the medium of instruction. Intensive overseas foreign language programs usually do not allow time for the study of other subject areas.

With the exception of the example of SA programs to Englishspeaking countries, what all of these language learning situations have in common, with or without formal instruction, is the opportunity for informal language learning outside of the language classroom. With respect to the development of FL proficiency, this is the defining issue in SA programs. Thus, the first step in outlining a framework for SA experiences is to establish an architecture of institutional types (see Figure 1, next page).

Each of these systems has counterparts or near counterparts in other parts of the world (cf. Coleman et al. 1991, cited in Freed 1995a; Regan 1995). The foreign exchange experience, for example, is available to secondary students in many countries (cf. Lussier et al. 1993; Marriott 1995), and Canada's provincial exchange program offers a similar program within that bilingual country (cf. Lapkin et al. 1995). 
Figure 1: A Taxonomy of Institutional Types Providing Study Abroad Experiences

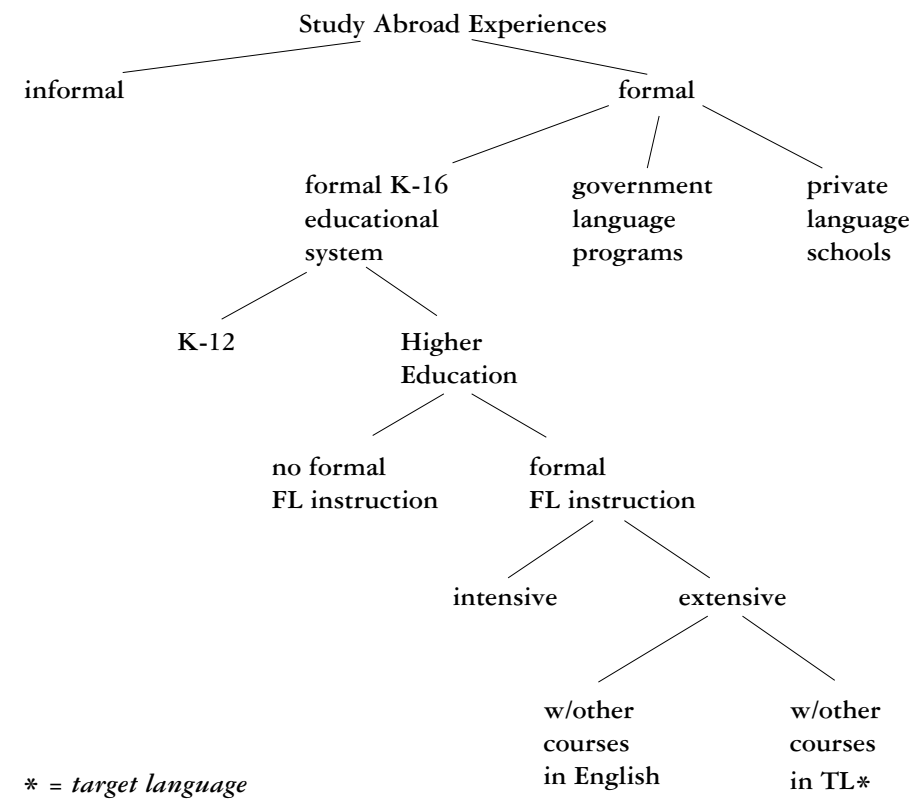

In looking at the effectiveness of SA programs for the development of foreign language proficiency, it is necessary to consider the findings from all language learning situations that provide opportunities for informal language learning. At the same time, one cannot lose sight of the variation among these program types with respect to philosophies, goals, student demographics, program design, and assessment — what will be referred to here as the language learning situation.

\section{Program Go a Is}

Implicit in the various program types are different goals for students enrolled in them. Brecht and Walton (1994) suggest that the goals of SA programs, whether under the auspices of a university or university consortium, a private language school, or a government training program, fall into two broad categories: those goals that they call "broadly educational," and those that are directed at foreign language proficiency. Broadly educational goals include the benefits derived from a general cultural experience in a foreign country, the promotion of international under- 
standing, and increased knowledge or expertise in a particular discipline or concentration. SA programs whose goals are exclusively broadly educational do not include a language study component.

For some of these programs, no prior foreign language learning is required. These include SA programs in other English-speaking countries, as well as overseas programs in other environments which require no foreign language proficiency. Examples include some AFS programs in Scandinavia or Asia or those SA programs in which "students are taught in English by faculty from the home institution" (Brecht and Walton 1994:217-18). Except for those rare cases in which students may "pick up" the host country language through informal out-of-class contact alone, without the benefit of formal instruction these programs have little to contribute to the dialogue surrounding the integration of SA programs into the foreign language curriculum.

In other SA programs with exclusively broadly educational goals, a working knowledge of the foreign language may be a prerequisite, for example those which sponsor advanced in-depth study of a disciplinary concentration such as Italian Renaissance art, the structure of the Israeli Kibbutz, or the management style in a Japanese auto manufacturing firm. For these programs, it is necessary to identify the specific foreign language skills needed to function in the foreign language environment, and the best ways to develop and assess those skills prior to the student's sojourn abroad.

The second type of goals, those directed at increased foreign language proficiency as a product of the SA experience, are inherent in all SA programs that include a foreign language component, but the notion of foreign language proficiency is itself an elusive one. Larsen-Freeman and Long point out that during the early years of SLA research, "the prevailing view held that language proficiency could be divided into unrelated skills (listening, speaking, reading and writing) and knowledge of language components (vocabulary, phonology and grammar)" (1991:38). Within the past twenty years, however, alternative views of language proficiency have been proposed. Oller (1976), for example, proposed a "global proficiency" as a unitary trait incapable of being divided into separate skills or components. Cummins (1980) has also proposed a kind of global language proficiency factor "which can be assessed by a variety of reading, writing, listening and speaking tests and which is strongly related to 
general cognitive skills ... and to academic achievement" (1980:176). He calls this Cognitive/Academic Language Proficiency, or CALP. He also proposes a second type of language proficiency, called Basic Interpersonal Communication Skills (BICS), which consists of the oral fluency and the sociolinguistically appropriate use of a language in everyday, interpersonal interactions. Sociolinguistic competence is a component of several other models as well. Rather than linguistic proficiency, Canale and Swain (1980) speak of communicative competence, which encompasses four components: grammatical, sociolinguistic, discourse, and strategic competence (Canale 1983). Global measures of proficiency commonly used in SA programs include oral proficiency interviews such as the ones developed by the Foreign Service Institute or by the American Council for the Teaching of Foreign Languages (ACTFL), although the latter is not without controversy (see, for example, Kramsch 1986 and Savignon 1985, and the discussion below on gender).

The complexity of the notion of language proficiency suggests that SA program goals directed at increased foreign language proficiency need to be specific with respect to what aspects of foreign language proficiency the program hopes to develop. But it is the contextual variables within the language learning situation which will determine the success of those goals. These variables include the type of target language, target populations, and structure of the overseas experience.

\section{Types of Languages Targeted}

There are at least two dimensions to language type. The first is the relative difficulty of the oral language to be learned by English-speaking students. The Educational Testing Service (ETS), for example, lists four groups of target languages taught in the Foreign Service Institute (FSI) according to expected levels of speaking proficiency (on a scale, ranging from 0 , equivalent to no proficiency, to 5 , educated native-like proficiency) after a specified length of training. For example, students learning a language like French or Spanish (Group I languages) can expect to attain between a $1+$ and a $2+$ on the ETS Oral Proficiency Interview (OPI) test after 16 weeks or 480 hours of instruction (Liskin-Gasparro 1982). Students studying Group II languages (for example, Greek, German, or Farsi) can expect to achieve between a 1 and 2 on the OPI during the same 
period. In the same amount of time, students of Group III languages (Bengali Hebrew, Russian, and Vietnamese, for example) can expect to attain between $0+$ and $1+$, while those of Group IV languages (Arabic, Chinese, Japanese, Korean) can expect scores of only $0+$ to 1 .

A separate but related dimension of language type concerns orthography. For example, Thai and Vietnamese are both Group III languages according to the ETS' expected levels of speaking proficiency, and typographically they share many features. However, Thai uses an Indic-based alphabet, while Vietnamese uses three distinct writing systems: Chinese characters, a demotic script called "southern script," and the Roman "national" or "standard script." It is the last which "serves as the medium of instruction at all three levels of education and has been successfully groomed as the official orthography" (Nguyên 1987: 780). Similarly, two other Group III languages, Russian and Polish, are both Slavic, but the former uses a Cyrillic alphabet while the latter uses a Latin one. Finally, all of the Group IV languages listed by the ETS use non-Roman systems, but they differ considerably one from the other. For example, one (Arabic) uses a right-to-left alphabet system. A second (Korean) uses a left-to-right alphabet in which letters forming a syllable are arranged as a rebus. Chinese uses a logographic or character system, and Japanese uses three systems simultaneously, a Chinese-based character system and two syllabary systems, katakana and hiragana. While speaking proficiency in these four Group IV languages may require comparable periods of training, it is not unreasonable that development of literacy skills among these languages may vary greatly.

This has at least two important implications for an evaluation of the impact of overseas study. First, research into the effects of the overseas experience on emerging foreign language literacy skills cannot ignore these orthographic differences. One can assume that development of literacy skills in an orthography different from that of the students' native language would take longer than in one similar to it. At the same time, the exposure to environmental print that the SA experience provides may facilitate the development of literacy in alternative orthographies. Huebner (1995), for example, found that beginning-level students of Japanese in an SA program performed better on a test of reading comprehension than did their counterparts in a comparable introductory Japanese program in a stateside university. Equally important, however, is the effect 
of exposure to environmental print on oral proficiency. Students studying languages with familiar or easily accessible orthographies may be in a better position to take advantage of environmental print for vocabulary development, for example, during their sojourns abroad, than students of languages with less accessible orthographies. To date, there is little research on the effects of environmental print on either literacy development or other aspects of foreign language proficiency in the study abroad context.

\section{Target Populations}

The emerging body of literature on the linguistic effects of SA programs has been directed toward questions such as who benefits most from a sojourn abroad, the distinguishing characteristics of the language of students who have studied abroad, students' perceptions of the language learning experience in an SA context, how those perceptions affect language learning, and the effects of other features of context (see Freed, this volume). Among the constellation of learner variables that will likely prove relevant to the issue are age, aptitude, gender, motivation, previous language learning experiences, and learning strategies.

Age. Within the larger field of SLA, the relationship between age and second language development has been much researched. Because the focus of this research has been on whether or not there is a critical or sensitive period for second language learning, most of it has looked at the differences between pre-adolescent, adolescent, and post-adolescent learners (see Long 1990). In a review of this literature, Krashen, Scarcella, and Long (1979) conclude that adults acquire a second language faster than children and older children faster than younger children, but that learners who begin study of a second language from childhood are more likely to achieve accent-free, native-like performance. Johnson and Newport (1989), however, report on data from 23 adults ranging in age from 17 to 39 which shows no relationship between the acquisition of morpho-syntax and age of onset of study for this group of learners, suggesting that the age differences among learners may be the result of a sensitive period around puberty and not of a general age effect. Yet anecdotal evidence from government language programs, for example, suggests that there may be age-related differences among adult learners as well. No docu- 
mented research is currently available which directly addresses the issue of a general age effect on the range of factors which constitute second language proficiency.

Foreign Language Aptitude. Aptitude has been defined as "some current state of capability of learning [a] task ... presumed to depend on some combination of more or less enduring characteristics of the individual" (Carroll 1981:84). Foreign language aptitude is taken to mean the capacity for learning a second language. Within the foreign language aptitude research, the most commonly used instrument to measure foreign language aptitude is the Modern Language Aptitude Test (MLAT, Carroll and Sapon 1959), although there are others (e.g., the Pimsleur Language Aptitude Battery, Pimsleur 1966; the Defense Language Aptitude Battery, Petersen and Al-Haik 1976; the York Language Aptitude Test, Green 1975; for a discussion of foreign language aptitude and the use of the MLAT, see Goodman, Freed, and McManus 1990).

While there is much debate over what constitutes foreign language aptitude, "the early research provided convincing evidence that classroom learners' language aptitude has a major effect on their success in learning an L2" (Ellis 1994:498). Subsequent research (e.g., Skehan 1989) has led others to suggest that language aptitude may be "more related to the academic/literacy skills than to oral/aural proficiency" (Larsen-Freeman and Long 1991:172). This interpretation is consistent with at least one study of an SA program. Reporting on a multi-year study of 658 students of Russian in an SA context, Brecht, Davidson, and Ginsberg (1993:22) report that language aptitude, as measured by two subparts of the MLAT, has a strong positive correlation with reading and listening gains, but not with gains in speaking skills. Freed (1996b) reports a similar finding in the use of the MLAT for predicting success in SA settings. This would suggest that assessment of the effects of the SA experience would need to control for language aptitude with respect to the development of CALP, but not where speaking skills are the primary goal.

Gender. When SLA research has looked at gender differences in SLA, the general pattern seems to suggest that females are better second language learners than males. This difference has been attributed to differences in attitudes to learning a second language (Burstall 1975), motivation to learn the second language (Gardner and Lambert 1972), and different ways of approaching the language learning task (Gass and Varonis 
1986; Bacon 1992; Bacon and Finnemann 1992). Whatever the specific reason, the differences which appear are attributed to social, rather than physiological, factors.

Social factors also seem to play a role in gender differences which have been reported in the literature on SA programs. In these cases, however, those factors work against females. For example, although she doesn't look at effects on proficiency, Twombly (1995) describes how cultural differences in perceived gender roles between North American students and their Costa Rican hosts affect the kinds of out-of-class contacts made with native speakers of Spanish during their SA experience. Carlson et al. (1990), in a study of 171 students from four American universities participating in SA programs in Germany and France, used pre- and postself-assessment questionnaires to assess language development during study abroad. They found that "the single most powerful predictor of language change was gender.... Examination of [mean scores on self-assessment scales] of the males and females both before and after study abroad showed that the greatest gain in language proficiency was made by the males" (Carlson et al. 1990: 78). Similarly, the large-scale Russian study mentioned above found that on average men outgain women in listening comprehension and oral proficiency (Brecht, Davidson and Ginsberg 1993:16).

Several studies of the SA experience suggest why this might be so. In a case study of four women learning Japanese as a foreign language in Japan, Siegal $(1994,1995)$ reports that for these women appropriate language use involves a knowledge of how Japanese women speak, as well as their view of the role of Japanese women and themselves while they are in Japan. Their failure to use appropriate language may be the result of lack of proficiency in Japanese in socio-culturally appropriate ways or of their refusal to accept "certain societal rules concerning the conduct of everyday [women's] behavior" (1995).

A preliminary analysis of the daily language learning journals of a sample of the 658 participants in the larger Russian study found that men and women spent their free time outside of class in similar activities, but that "American women may have fewer-and qualitatively differentopportunities to speak in a mixed gender setting than American males" (Brecht and Robinson 1993:19). In a more extensive analysis of diaries from this same study, Polyani (1995) attributes the women's lower scores 
on both tests of listening and oral proficiency to gender-related problems:

In Russia, in the field, (the women in SA programs) are learning not to be "Russian language speakers" but to be "women Russian language speakers." Rather than discussing music, politics and debating the relative merits of a totally free market based economy, they are learning how to get out of humiliating social encounters, how to interpret the intentions of even polite-seeming educated young men, how to get themselves bome in one piece after an evening spent in fending off unwanted advances. They are learning to be more subtle about bandling encounters in Russian than they would bope to ever need to be in English. They become skilled at saying "No. Get your hands off me." to young men whose friendship and belp they need to get to know the country well and to do the job they came over to do.... (T) be women do succeed in learning precious linguistic and cultural survival skills, yet these hard won skills are not those defined as skills which need to be learned. (1995)

These studies suggest that women are not only faced with out-ofclass encounters which are both quantitatively and qualitatively different from those of their male colleagues, they have also not been prepared in their pre-SA language programs to deal with these differences. Furthermore, assessment instruments such as the ACTFL Oral Proficiency Interview (OPI), commonly used to measure proficiency gains, fail to measure what they have learned of the language during their sojourn in the host country.

Motivation. As Ellis (1994: 517) points out, "motivation in second language $\{\mathrm{L} 2\}$ learning constitutes one of the most fully researched areas of individual differences," and numerous studies have provided evidence that indicates that motivation is an important indicator of foreign language learning success. Yet despite the abundance of research in the area, it is not without controversy. The bulk of the motivation research in SLA has focused on the distinction between integrative and instrumental motivation (cf. Gardner 1985), the former arising from a desire to integrate with the target language (TL) community and the latter from material rewards associated with FL learning success. It can be assumed that each of these motivates participants in SA programs. While Gardner maintains the superiority of integrative motivation for FL learning, instrumental 
motivation has shown to be an effective predictor in environments where learners have little interest in the target culture (Gardner and Lambert 1972, Lukmani 1972). Other researchers find the distinction difficult to maintain (e.g., Ely 1986, Crookes and Schmidt 1989). Others still provide evidence that motivation may be a result of FL success as much as it is a predictor of it (Savignon 1972; Hermann 1980; Strong 1984; Freed 1990, 1995b).

This last point suggests that motivation can change over time, with as yet unexplored implications for SA programs. Several studies which compare the effects of a sojourn abroad with similar language courses at home have controlled for motivation (e.g., DeKeyser 1986, 1991; Huebner 1995), but few (exceptions include Gardner, Smythe, and Brunet 1977, cited in Larsen-Freeman and Long 1988: 20; Coleman et al. 1994, cited in Freed 1995a) have looked at changes in motivation as a result of the immersion experience.

Previous Non-target-language Language Learning Background. Another difference among individual learners likely to influence the effects of a sojourn abroad on language proficiency is the learner's proficiency in his or her first language and in foreign languages other than the target. While most students who participate in SA programs are assumed to have relatively well-developed first language skills, it would be remiss to ignore this variable when measuring the benefits of the SA experience, especially with respect to the development of CALP. Cummins' (1980) interdependence hypothesis proposes a common underlying proficiency for CALP, which is transferable across a student's two languages. Highly developed CALP in a student's first language is likely to aid in the development of second language literacy skills.

At the same time, knowledge of languages other than the target language or the native language of the students may also have a positive effect on the development of the target language. For example, Rivers (1979) reports that her knowledge of French (her second language) facilitated her subsequent learning of Spanish. Certainly, cognates played a role in this case, but it may also be that knowledge of a second language constrains the hypotheses that learners formulate regarding the target language. It may be, too, that having successfully learned a second language already, the learner has "learned how to learn." Brecht, Davidson, and Ginsberg suggest as much when they state that "students gain more in- 
country if they have had another foreign language in addition to Russian in high school or college" (1993: 20). In any case, this is an area which has received little attention in research on language learning in SA contexts.

Learning Strategies. Learning strategies are those unconscious or conscious activities undertaken by learners to promote learning (cf. LarsenFreeman and Long 1991:212). It has been proposed that the teaching of learning strategies as a part of the second or foreign language curriculum can be of benefit to learners (O'Malley et al. 1985). At the same time, research on SA programs suggests that learners do not take full advantage of the opportunities for out-of-class contacts to enhance their learning of the target language while studying overseas. Huebner (1995) administered the Strategy Inventory for Language Learning (Oxford 1990) to students in intensive Japanese programs both at home and in Japan at the beginning and again at the end of the course. Not only did he find little difference between the two groups, there was also little change within the Japan-based group in the strategies they employed at the beginning of their overseas sojourn and at the end.

As a part of the larger Russian study, Miller and Ginsberg (1995) analyzed the journals of a sample of students for their beliefs about language and methods of language learning. They found that while students are critical of what takes place in their formal language learning classrooms, they approach the out-of-class experiences with the target language in much the same way that they approach the tasks involved in formal classroom learning. Miller and Ginsberg maintain that as a result, students do not take full advantage of the language learning opportunities that a sojourn abroad affords them. It seems that Wenden's suggestion that language teachers should no longer consider their domain to be simply the teaching of language is especially apropos to SA programs:

Learners must learn how to do for themselves what teachers typically do for them in the classroom. Our endeavors to help them improve their language skills must be complemented by an equally systematic approach to belping them develop and refine their learning skills. Learner training should be integrated with language training. (1985:7)

Background in the Target Language. Much of the research on the linguistic effectiveness of SA programs has focused on the question of when in the learners' FL learning careers they might optimally benefit from a 
sojourn abroad. The results have not always been consistent. Research on the linguistic effects of three-month interprovincial exchanges among junior and senior high school students in Canada finds that students with initially lower French language proficiency made greater gains as a result of submersion in a French environment, especially for listening and oral skills (Lapkin et al. 1995). Furthermore, analysis of diaries and questionnaires suggest that most of the significant learning experiences of the interprovincial exchange students occur outside the classroom. The researchers conclude that "[ $[\mathrm{t}] \mathrm{he}$ importance of frequent and sustained interactions with native speakers, it seems, cannot be overstated in achieving impressive linguistic gains in a three-month exchange" (1995:91). Freed (1995b) also finds more growth for those with lower levels of proficiency.

Brecht, Davidson, and Ginsberg (1993) report that in the Russian study, regardless of proficiency level, those students with higher presojourn FL reading and grammar test scores were more likely than students with lower scores to gain in all other skills, including gains on the OPI and listening comprehension measures. This is particularly true for groups of learners who have reached a threshold level of $1+/ 2$ on the OPI. Based on these findings, they advocate an investment in grammar and reading prior to SA. They also found the most growth in language proficiency during SA among students at lower levels of proficiency. While their study was based on undergraduate and graduate students, and the Canadian study was of adolescents, other factors (e.g., age, motivation) also need to be taken into account in generalizing from these results.

That SA participants at various levels of FL proficiency benefit differently from the overseas experience is apparent in the work of Freed (1990). In a study of university-level SA students in France, she found that those at advanced levels of FL study benefit more from "non-interactive contact" (i.e., reading books, watching television, etc.) with the TL. Intermediate-level students, on the other hand, benefit most from "interactive" (speaking with family and friends) out-of-class contact. Other studies offer data to suggest that even students at beginning levels of FL study may gain added benefits from the SA experience (i.e., Huebner 1995).

Given these findings, there may not be one best time for all students to study abroad. A definitive answer may ultimately rest on other variables discussed above as well as individual differences such as personality 
type or cognitive style. It may also rest on variables inherent in program design.

\section{Program and Course Design}

SA programs vary with respect to design features perhaps as much as foreign language programs in general. These variables can be seen in terms of the amount and quality of out-of-class target language contact that SA programs foster, and the extent to which these programs prepare students for this contact, both before and during the sojourn abroad. Because SA programs are often a part of a larger foreign language program, post-SA follow-up to sustain and build upon gains attributed to the overseas experience becomes an important component as well.

Out-of-class Contact and Language Acquisition. As has been pointed out above, the quantity and quality of out-of-class contact is related to such learner variables as gender, learning strategies, and background in the target language, as well as to type of out-of-class contact. But programs vary with respect to the extent to which opportunities for out-of-class contact are built into them. Programs which house American students together in American enclaves (Brecht and Walton 1994) provide for fewer such opportunities than those which house students with host-country students in dormitories. Host family living arrangements may provide even more such opportunities. In situations where students are left to themselves to find living arrangements, individual learner differences may take on more importance with respect to the opportunities students seek out for informal out-of-class target language contact.

The Formal Instructional Context and Language Acquisition. One overriding issue in SLA research concerns the ultimate value of language instruction in target language contexts: Does language instruction help at all in these contexts? In a review of studies comparing naturalistic versus formal instruction, Long (1983, cited in Chaudron 1988) argues that "the outcomes favor instruction, all other factors being equal" (emphasis in original, 1988:4). Within the SA context, the corresponding question would be whether formal instruction alongside of informal contact facilitates learning. Studies of SA programs, drawing on student journals and interviews, provide some insight into students' impressions of the value of classroom instruction vis a vis their out-of-class experiences (cf. Carlson et 
al. 1990; Brecht and Robinson 1993; Miller and Ginsberg 1995). But lacking among the SA research is any close look at what actually happens in the classroom and the relationship between that and FL attainment during the sojourn abroad.

Among the areas yet to be explored in in-country classrooms are the design features of the course itself, the nature of classroom language, and methods of student assessment. Course design features encompass such variables as the intensity and duration of the course, the specification and organization of the course syllabus, and the role of classroom resources. SA courses, as noted earlier, can be either intensive or extensive, and they can range in length from several weeks to a full year. The syllabus may be organized around structural features of the language, notions and functions that language performs, situations students are likely to find themselves in, tasks students are expected to perform in the target language, or some combination of these. Among the classroom resources SA programs may draw upon are textbooks, authentic oral and written materials in the target language, computers and language laboratories. Spada (1985, 1986) suggests that the learners' informal contact with the target language may interact with instructional differences to produce variation in improvement in proficiency. The extent to which design features have been modified from regular home-based courses to meet the immediate communicative needs of SA students will surely affect the degree to which those students are able to take advantage of their out-of-class contacts in the target language.

Two other variables inherent in the SA situation and crucial to how language is learned are the nature of classroom language - who talks, how much, in what language and for what purposes - and the cultural norms of the target language population, of the students, and of the classroom. Are students taught to follow target culture norms and to understand, anticipate, avoid, and resolve cultural conflicts? To date, this issue has received little attention in the research on the effectiveness of SA programs.

Because students' perceptions of what is most relevant in the content of a course are shaped by "what will be on the test," another important factor in the SA course design is the degree to which it is test-oriented and the nature of those exams. Do the tests measure the kinds of skills that students are expected to develop from their sojourn abroad? This is an issue 
not only of course design but also with respect to any evaluation of the effectiveness of the linguistic effects of SA programs globally.

Post-instruction Follow-up. Post-instruction follow-up to formal SA language instruction may take the form of re-entry courses for students returning to their home institutions, or in the case of students who continue their sojourn abroad after the completion of formal language instruction (e.g., the Peace Corps example), support structures in the host country. Pilot studies from the massive European Language Proficiency Survey (35,000 students in approximately 100 institutions; Coleman et al. 1994, cited in Freed 1995a) suggest that student growth in the target language slows down radically upon their return from a year abroad. These results point to the importance of follow-up to sustain and build upon gains attributed to the overseas experience.

\section{Research Approaches, Methods and $S$ A P r o g a m s}

All of the factors discussed in the preceding sections need to be taken into account in assessing the ways in which the SA experience can optimize language learning. In looking at how to assess this experience, it may be useful to adopt a distinction made for the analysis of teaching method (Richards and Rogers 1986) and distinguish between research approaches, methods and techniques. Approach involves phenomenological and epistemological beliefs within which research is conducted, in this case about the nature of language, language learning, and research, about the nature of observation and experience, about the nature of "truth." Methodology involves design issues such as what research questions or hypotheses are raised, what and who will be studied, the extent of data collected, and how findings are interpreted and presented. Techniques include the kinds of data that will be collected and how they are analyzed.

The research approaches taken are determined by the philosophical and theoretical stance of the researchers, which in turn is the result of the researchers' own personal experiences and academic socialization, itself a result of extensive coursework and apprenticeship. The broadly defined distinction often found in the literature between quantitative and qualitative research approaches is an example. Quantitative research, sometimes called “statistical studies" (cf. Brown 1991), involves an etic, or outsider's, per- 
spective. Typically, quantitative researchers determine the variables under investigation, hold all but one of them constant, collect data and analyze it using statistical procedures and interpret their results according to preestablished criteria. Research within this paradigm tends to be concerned with mental processes. Qualitative research, in contrast, is holistic in that it attempts to take into account all relevant contextual influences related to the behavior or event being explained. It involves an emic perspective, as Hymes says, an account "in terms of features relevant in the behavior in question" (1974: 11), in order to arrive at the meanings of events and actions from the perspective of the participants. Research within this paradigm involves case studies and thick descriptions, and employs a variety of techniques (see below) to gather data over an extended engagement in a particular social setting or with a particular community.

Evaluation criteria for quantitative studies are expressed in terms of validity (“Am I measuring what I say I am measuring?”), reliability ("Are the results replicable?"), and generalizability ("Can the findings be applied to other populations?”). The prototypical quantitative study is experimental. Methodologically, a true experimental study minimally involves two essential features: there must be both an experimental and a control group, and subjects in each group must be randomly selected. Because human behavior with respect to whether or not someone will study abroad is difficult to dictate for experimental purposes, many studies employ methodologies which omit one or another of these criteria. Therefore, quasi-experimental research, in which one or another of these criteria is missing (Larsen-Freeman and Long 1991:19), or pre-experimental research, which fails to meet either of these criteria (ibid.), are often the norm in quantitative studies in education and can also provide useful insights into SLA processes, although such a design precludes making statements of causation or generalization. One example cited by Larsen-Freeman and Long is the one-group pre-test/post-test type, in which students are tested before a given treatment (for example, the SA experience) and then again afterwards. As a way of compensating for these problems, many SA studies have employed multiple research methodologies. Those that do often provide the richest quantitative pictures of the linguistic effects of SA.

Whereas quantitative research aims for generalizability, the goal of qualitative research is to generate assertions about patterns found in the 
data which are specific to the particular group or situation studied, which hold meaning for the members of that group or participants in the situation, and which are transferable to other groups or social situations. Whereas quantitative research is concerned with issues of validity and reliability, qualitative research is evaluated in terms of credibility and dependability from the point of view of those being researched. This is achieved through prolonged engagement, persistent observation, and triangulation, using multiple sources, techniques, and/or investigators. The prototypical qualitative research project is the ethnographic study. Davis (1995) provides an accessible discussion of how qualitative theory and methods apply to research in language education. One of the methodological issues she identifies is that of negotiating entry and research ethics. Participants in the study must be as informed as possible about the purposes, activities and burdens entailed in the study, and they must be protected from possible risks. At the same time, researchers must ensure that they will have the best possible access to the research site. This entails negotiating with the research participants on an on-going basis the data collection techniques that will be used. It also requires some exchange of services or reciprocity. In an SA context this may take the form of sharing with students the results of the study to make them more conscious of what language learning factors will maximize their learning. The data collection process itself is cyclical in nature, involving collection of data, analysis, hypothesis formation, additional data collection to test and revise hypotheses, until new data sufficiently supports the hypotheses put forth. Brecht and Robinson (1995, 1993) and Siegal (1994) are examples of qualitative research approaches to SA.

These various approaches and methods are not necessarily incompatible. Each provides another perspective from which to look at language development and contributes to an understanding of the complexity and richness of that process in an SA context. Together, they shed light on what is universal to the SA experience and what is unique to a particular SA context.

\section{Re s e a rch Tech n i que s}

While techniques such as participant observation (Spradley 1980), the ethnographic interview (Spradley 1979), and journals are usually asso- 
ciated with qualitative studies, and discrete item grammaticality judgement tasks, multiple choice questionnaires, and Flanders observation matrixes (Allwright 1988), for example, are associated with quantitative approaches to research, instrumentation should not be confused with research approach. Indeed, as Davis (1995) points out, qualitative studies often use statistics while quantitative studies are often enriched with data derived from interviews, for example. And in fact, both approaches are enriched by multiple sources of data.

Within the SA context, a number of instruments have been used to measure the linguistic effects of the SA experience. Early studies relied on discrete item test scores to measure linguistic growth (Carroll 1967, Willis et al. 1977). Subsequent researchers (e.g., Veguez 1984, Kaplan 1989, Freed 1990, Milleret 1990, Hart et al. 1994) have pointed out the potentially confounding ceiling effects of discrete point tests such as the College Entrance Examination Board (CEEB) or the MLA Cooperative Tests.

Questionnaires and surveys have been used to gather information on student language use (Kaplan 1989, Freed 1990), learning strategies (Huebner 1995) and affective variables such as attitude and motivation (DeKeyser 1986, 1991; Freed 1990, 1995b; Huebner 1995). They have also been used as indicators of students' self-assessment of proficiency gained (e.g., Carlson et al. 1990, Maera 1994, Lapkin et al. 1995). Meara's (1994, cited in Freed 1995a) analysis of a self-assessment questionnaire administered to 586 SA students from the more general Nuffield Modern Language Inquiry found that the majority of students reported improved oral-aural skills as a result of the year abroad experience; fewer than half felt that they had made progress in reading and writing. But the value of self-assessment questionnaires as a surrogate for other measures of proficiency gain is questionable. Lapkin et al. (1995), using both self-assessment questionnaires and tests of listening and reading comprehension, speaking and writing, conclude: "Overall, the results were disappointing in that the correlational data would not encourage us to dispense with language testing in favour of self-assessment scales."

Perhaps the most commonly used measure of oral proficiency in SA programs is the TL interview (especially the ACTFL OPI). Freed (1995b), however, points to at least one limitation to the OPI as a global measure of language use: because of its non-linear construction, the OPI is often 
unable to discriminate progress made by students at the upper levels of the proficiency scale. Taped interview data have also been used as the basis of collection of data and the subsequent analysis of the acquisition of specific grammatical features of the TL (e.g., Ryan and Lafford 1992, Gunterman 1992a, 1992b), fluency (Freed 1995b), and sociolinguistic competence (e.g., Marriott 1995, Regan 1995).

Learners' diaries and journals provide insights into affective variables as well as communication and learning strategies (DeKeyser 1986, 1991; Brecht and Robinson 1993; Miller and Ginsberg 1995; Polyani 1995). The discussion of gender differences above points to the value of diary studies in native language interviews to enrich our understanding of the results of quantitative studies.

Communication games, picture descriptions, and role play situations have been used to look at communication strategies (DeKeyser 1986, 1991; Lafford 1995) and the development of sociolinguistic competence (Marriott 1995). Studies of sociolinguistic (Seigal 1994, 1995) and strategic competence (Hashimoto 1994, cited in Marriott 1995) have also relied on data from tape recordings of natural conversations.

\section{Conclusions}

Although the research in SA is still in its infancy, as educators begin to explore avenues for reform and improvement of foreign language education, attention to SA programs will increase. This paper has attempted to provide a framework for the evaluation of these programs by identifying some of the variables which must be taken into consideration in evaluating the range of programs that all fall under the rubric of "Study Abroad." In the process, it has also reviewed some of the literature on that topic, and broadly outlined some of the research issues, for SLA and foreign language pedagogy in general, and for SA in particular. The picture that emerges is both complex and incomplete. SA programs vary with respect to their placement in educational institutions, their goals, their target languages and populations, and their program and course designs.

As teachers, program administrators, and students without formal training in the research traditions of applied linguistics become more involved in looking analytically and empirically at the SA experience, they will find it necessary to familiarize themselves with that literature, 
both to identify the important questions to ask, and to examine models for answering them. Publications on second language research methods (e.g., Seliger and Shohamy 1989), both quantitative (e.g., Hatch and Farhady 1984, Brown 1988, Scholfield 1995) and qualitative (e.g., Davis and Lazaraton 1995), and on language classroom research methods (e.g., Allwright 1988, Chaudron 1988, van Lier 1988) will prove useful. But perhaps the most promising prospect for a burgeoning literature on the linguistic effects of SA is research partnerships between those who have the required knowledge and experience in the relevant research traditions but lack access to programs, and those who are actively involved in programs but lack the requisite training for research.

\section{References}

Allwright, D. 1988. Observation in the Language Classroom. London: Longman.

Bacon, S. 1992. The Relationship Between Gender, Comprehension, Processing Strategies, and Cognitive and Affective Response in Second-language Listening. Modern Language Journal 76: 160-78. Bacon, S., and M. Finnemann. 1992. Sex Differences in Self-reported Beliefs about Foreign-language Learning and Authentic Oral and Written Input. Language Learning 42: 471-95.

Brecht, R. D., D. E. Davidson, and R. B. Ginsberg. 1993. Predictors of Foreign Language Gain during Study Abroad. Occasional Papers of the National Foreign Language Center. Washington, D.C.: Johns Hopkins University.

Brecht, R. D., and J. L Robinson. 1995. On the Value of Formal Instruction in Study Abroad: Student Reactions in Context. Second Language Acquisition in a Study Abroad Context, ed. B.F. Freed. Amsterdam and Philadelphia: John Benjamins.

— . 1993. Qualitative Analysis of Second Language Acquisition in Study Abroad: The ACTR/NFLC Project. Occasional Papers of the National Foreign Language Center. Washington, D.C.: Johns Hopkins University.

Brecht, Richard, and A. Ronald Walton. 1994. Policy Issues in Foreign Language and Study Abroad. Annals of the American Academy of Political and Social Sciences 532: 213-225. 
Brown, J. D. 1991. Statistics as a foreign language - Part I: What to look for in reading statistical language studies. TESOL Quarterly 25: 569-86.

Burstall, C. 1975. Factors Affecting Foreign-language Learning: A Consideration of Some Relevant Research Findings. Language Teaching and Linguistics Abstracts 8: 105-25.

Canale, M. 1983. From Communicative Competence to Language Pedagogy. Language and Communication ed. J. Richards and R. Schmidt. London: Longman.

Canale, M., and M. Swain. 1980. Theoretical Bases of Communicative Approaches to Second Language Teaching and Testing. Applied Linguistics 1:1-47.

Carlson, J. S., B. B. Burn, J. Useem, and D. Yachimowicz. 1990. Study Abroad: The Experience of American Undergraduates. New York: Greenwood Press.

Carroll, J. B. 1967. Foreign Language Proficiency Levels Attained by Language Majors Near Graduation from College. Foreign Language Annals 1: 131-151.

— . 1981. Twenty-five Years of Research on Foreign Language Aptitude. Universals in Language Learning Aptitude, ed. K. C. Diller, Rowley, MA: Newbury House.

Carroll, J. B., and S. Sapon. 1959. Modern Language Aptitude Test-Form A. New York: The Psychological Corporation.

Chaudron, C. 1988. Second Language Classrooms: Research on Teaching and Learning. Cambridge: Cambridge University Press.

Coleman, J., R. Grotjahn, C. Klein-Braley, and U. Raatz. 1994. The European Language Proficiency Survey: A Comparative Investigation of Foreign Language Learners in Schools and Universities in Several European Countries. Language Testing Update.

Crookes, G., and R. Schmidt. 1989. Motivation: Reopening the Research Agenda. University of Hawaii Working Papers in ESL 8: 21756.

Cummins, J. 1980. The Cross-Lingual Dimensions of Language Proficiency: Implications for Bilingual Education and the Optimal Age Issue. TESOL Quarterly 14.2: 175-88.

Davis, K. A. 1995. Qualitative theory and methods in applied linguistics research. TESOL Quarterly 29.3: 427-53. 
Davis, K. A. and A. Lazaraton, eds. 1995. TESOL Quarterly, Special-Topic Issue: Qualitative Research in ESOL 29.3.

DeKeyser, R. 1986. From Learning to Acquisition? Foreign Language

Development in a U. S. Classroom and During a Semester Abroad.

Unpublished Ph.D. dissertation, Stanford University.

— . 1991. Foreign Language Development during a Semester Abroad.

Foreign Language Acquisition Research and the Classroom ed. B.F. Freed. Lexington, MA: D. C. Heath.

Ellis, Rod. 1994. The Study of Second Language Acquisition. Oxford: Oxford University Press.

Ely, C. 1986. Language Learning Motivation: A Descriptive and Causal Analysis. Modern Language Journal 70: 28-35.

Ferguson, C. A. 1975. Toward a Characterization of English Foreigner Talk. Anthropological Linguistics 17: 1-14. [Repr. in Second Language Learning ed. B. W. Robinett and J. Schacter. Ann Arbor: University of Michigan Press, 1983.]

- . 1971. Absence of Copula and the Notion of Simplicity: A Study of Normal Speech, Baby Talk, Foreigner Talk and Pidgins.

Pidginization and Creolization of Languages, ed. D. Hymes. New York: Cambridge University Press.

Freed, Barbara F. 1995a. Language Learning and Study Abroad. Second Language Acquisition in a Study Abroad Context, ed. B.F. Freed. Amsterdam and Philadelphia: John Benjamins.

- . 1995b. What Makes Us Think That Students Who Study Abroad

Become Fluent? Second Language Acquisition in a Study Abroad

Context, ed. B.F. Freed. Amsterdam and Philadelphia: John

Benjamins.

— . 1990. Language Learning in a Study Abroad Context: The Effects of Interactive land Non-Interactive Out-of-Class Contact on

Grammatical Achievement and Oral Proficiency. Linguistics, Language Teaching and Language Acquisition: The Interdependence of Theory, Practice and Research (GURT 1990) ed. J. E. Alatis.

Washington, D. C.: Georgetown University Press.

- . 1978. Foreigner Talk: A Study of Speech Adjustments Made By Native

Speakers of English in Conversation with Non-Native Speakers.

Unpublished Ph.D. dissertation, University of Pennsylvania.

Gardner, R. 1985. Social Psychology and Second Language Learning: The 
Role of Attitude and Motivation. London: Edward Arnold.

Gardner, R., and W. Lambert. 1972. Attitudes and Motivation in Second Language Learning. Rowley, MA: Newbury House.

Gardner, R., P. Smythe, and G. Brunet. 1977. Intensive Second Language Study: Effects on Attitudes, Motivation and French Achievement. Language Learning 27: 243-62.

Gass, S., and Selinker, L. 1994. Second Language Acquisition: An Introductory Course. Hillsdale, NJ: Lawrence Erlbaum Associates.

Gass, S., and E. Varonis. 1986. Sex Differences in NNS/NNS Interaction. Talking to Learn: Conversation in Second Language Acquisition ed. R. R. Day. Rowley, MA: Newbury House.

Goodman, J. B., B. Freed, and B. McManus. 1990. Determining Exemptions from Foreign Language Requirements: Use of the Modern Language Aptitude Test. Contemporary Educational Psychology 15: 131-41.

Green, P. 1975. Aptitude Testing: An On-going Experiment. AudioVisual Language Journal 12: 205-10.

Gunterman, G. 1995. The Peace Corps Experience: Language Learning in Training and in the Field. Second Language Acquisition in a Study Abroad Context ed. B.F. Freed. Amsterdam and Philadelphia: John Benjamins.

—. 1992a. An Analysis of Interlanguage Development Over Time: Part I, Por and Para. Hispania 75:177-87.

- . 1992b. An Analysis of Interlanguage Development Over Time: Part II, Ser and Estar. Hispania 75:1294-1303.

Hart, D. S., S. Lapkin, and M. Swain. 1994. Impact of a Six-month Bilingual Exchange Program: Attitudes and Achievement. Report to the Department of the Secretary of State. Toronto: OISE Modern Language Centre.

Hashimoto, H. 1994. Language Acquisition of an Exchange Student within the Homestay Environment. Journal of Asian Pacific Communication 4.4 .

Hatch, E. and H. Farhady. 1982. Research Design and Statistics for Applied Linguistics. Rowley, MA: Newbury House.

Hermann, G. 1980. Attitudes and Success in Children's Learning of English as a Second Language: The Motivational vs. the Resultative Hypothesis. English Language Teaching Journal 34: 247-54. 
Huebner, Thom 1995. The Effects of Overseas Language Programs: Report on a Case Study of an Intensive Japanese Course. Second Language Acquisition in a Study Abroad Context ed. B.F. Freed. Amsterdam and Philadelphia: John Benjamins.

Hymes, D. 1974. Foundations in Sociolinguistics: An Ethnographic Approach. Philadelphia: University of Pennsylvania.

Johnson, J. S., and E. L. Newport. 1989. Critical Period Effects in Second Language Learning: The Effects of Maturational State on the Acquisition of English as a Second Language. Cognitive Psychology 21: 60-99.

Kaplan, M. A. 1989. French in the Community: A Survey of Language

Use Abroad. The French Review 63: 290-301.

Kramsch, C. 1986. From Language Proficiency to Interactional

Competence. Modern Language Journal 70: 366-72.

Krashen, S. D., R. C. Scarcella, and M. H. Long. 1979. Age, Rate, and

Eventual Attainment in Second Language Acquisition. TESOL

Quarterly 13: 573-82.

Lafford, B. A. 1995. Getting Into, Through and Out of a Situation: A

Comparison of Communicative Strategies Used by Students

Studying Spanish Abroad and "At Home." Second Language

Acquisition in a Study Abroad Context ed. B.F. Freed. Amsterdam and Philadelphia: John Benjamins.

Lambert, Richard D. 1994. Some Issues in Language Policy for Higher

Education. Annals of the American Academy of Political and Social

Sciences 532:123-37.

Lapkin, S., D. Hart, and M. Swain. 1995. A Canadian Interprovincial

Exchange: Evaluating the Linguistic Impact of a Three-Month Stay

in Quebec. Second Language Acquisition in a Study Abroad Context ed.

B.F. Freed. Amsterdam and Philadelphia: John Benjamins.

Larsen-Freeman, D., and M. H. Long. 1991. An Introduction to Second

Language Acquisition Research. New York: Longman Inc.

Liskin-Gasparro. 1982. ETS Oral Proficiency Testing Manual. Princeton,

NJ: Educational Testing Service.

Long, M. H. 1981. Input, Interaction and Second Language Acquisition.

In Native Language and Foreign Language Acquisition, Annals of the

New York Academy of Sciences ed. H. Winitz. 379: 259-78.

— . 1983. Does Second Language Instruction Make a Difference? A 
Review of Research. TESOL Quarterly 17: 359-82.

— . 1990. Maturational Constraints on Language Development. Studies in Second Language Acquisition 12: 251-85.

Lukmani, Y. 1972. Motivation to Learn and Language Proficiency. Language Learning 22: 261-73.

Lussier, D., C. E. Turner, and S. Desharnais. 1993. Measuring Second Language (L2) Proficiency in High School Level Exchange Students. The Canadian Modern Language Review 49:526-49.

Marriott, Helen. 1995. The Acquisition of Politeness Patterns by Exchange Students in Japan. Second Language Acquisition in a Study Abroad Context ed. B.F. Freed. Amsterdam and Philadelphia: John Benjamins.

- In press. Acquiring Sociolinguistic Competence: Australian Secondary Students in Japan. Journal of Asian Pacific Communication 4.4 .

Meara, P. 1994. The Year Abroad and Its Effects. Language Learning Journal 10: 32-38

Miller, L., and R. B. Ginsberg. 1995. Folkloristic Theories of Language Learning. Second Language Acquisition in a Study Abroad Context ed. B.F. Freed. Amsterdam and Philadelphia: John Benjamins.

Milleret, M. 1990. Assessing the Gain in Oral Proficiency from Summer Foreign Study. Paper presented at the Summer Meeting of the American Association for the Teaching of Spanish and Portuguese.

Nguyên, D.-H. 1987. Vietnamese. The World's Major Languages ed. B. Comrie. 777-96. New York: Oxford University Press.

Oller, J. 1976. Evidence for a General Language Proficiency Factor: An Expectancy Grammar. Der Neuren Sprachen 2: 165-71.

O’Malley, J., A. Chamot, G. Stewner-Manzanares, R. Russo, and L. Küpper. 1985. Learning Strategy Applications with Students of English as a Second Language. TESOL Quarterly 19: 557-84.

Oxford, R. 1990. Language Learning Strategies: What Every Teacher Should Know. New York: Newbury House.

Petersen, C., and A. Al-Haik. 1976. The Development of the Defense Language Aptitude Battery (DLAB). Educational and Psychological Measurement 36: 369-80.

Pimsleur, P. 1966. Pimsleur Language Aptitude Battery (PLAB). New York: Harcourt Brace Jovanovich. 
Polanyi, L. 1995. Language Learning and Living Abroad: Stories from the Field. Second Language Acquisition in a Study Abroad Context ed. B.F. Freed. Amsterdam and Philadelphia: John Benjamins.

Regan, V. 1995. The Acquisition of Sociolinguistic Native Speech Norms: Effects of a Year Abroad on L2 Learners of French. Second Language Acquisition in a Study Abroad Context ed. B.F. Freed. Amsterdam and Philadelphia: John Benjamins.

Richards, J. C. and T. Rogers. 1986. Approaches and methods in language teaching. New York: Cambridge University Press.

Rivers, W. 1979. Learning a Sixth Language: An Adult Learner's Diary. Canadian Modern Language Review 36: 67-82.

Ryan, J. M. and B. Lafford. 1992. Acquisition of Lexical Meaning in a Study Abroad Environment: Ser and Estar and the Grenada Experience. Hispania 75:714-22.

Savignon, S. 1985. Evaluation of Communicative Competence: The ACTFL Provisional Guidelines. Modern Language Journal 69: 12933.

Scholfield, P. 1995. Quantifying Language: A Researcher's and Teacher's Guide to Gathering Language Data and Reducing it to Figures.

Clevedon, Avon: Multilingual Matters.

Seliger, H. and E. Shohamy. 1989. Second Language Research Methods. Oxford: Oxford University Press.

Siegal, M. 1995. Individual Differences and Study Abroad: Women Learning Japanese in Japan. Second Language Acquisition in a Study Abroad Context ed. B.F. Freed. Amsterdam and Philadelphia: John Benjamins.

— 1994. Looking East: Learning Japanese as a Second Language in Japan and the Interaction of Race, Gender and Social Context. Unpublished Ph.D. dissertation, University of California, Berkeley.

Skehan, P. 1986. Where Does Language Aptitude Come From? Spoken Language ed. P. Meara. London: CILT.

Spada, N. 1986. The Interaction Between Type of Contact and Type of Instruction: Some Effects on the L2 Proficiency of Adult Learners. Studies in Second Language Acquisition 8: 181-200.

- . 1985. Effects of Informal Contact on Learners' L2 Proficiency. TESL Canada Journal 2: 51- 62.

Strong, M. 1984. Integrative Motivation: Cause of Result of Second 
Language Acquisition. Language Learning 34: 1-14.

Swain, M. 1985. Communicative Competence: Some Roles of Comprehensible Input and Comprehensible Output in Its Development. In Input in Second Language Acquisition ed. S. M. Gass and C. G. Madden, Rowley, MA: Newbury House.

Twombly, S. B. 1995. Piripos and friendships: Gender and culture clash in study abroad. Frontiers: The Interdisciplinary Journal of Study Abroad 1: $1-27$.

van Lier, L. 1988. The Classroom and the Language Learner. London: Longman.

Veguez, R. 1984. The Oral Proficiency Interview and the Junior Year Abroad: Some Unexpected Results. Paper presented at the Northeast Conference on the Teaching of Foreign Language. New York, NY.

Wenden, A. 1985. Learner Strategies. TESOL Newsletter 19:1, 4-5, 7.

Willis, F., G. Doble, U. Sankarayya, and A. Smithers. 1997. Residence Abroad and the Student of Modern Languages: A Preliminary Study. Bradford: University of Bradford Modern Language Centre. 